\title{
Towards an Effective Decision Support System for Diabetic Foot Ulcers Diagnostic and Treatment Assessment
}

\author{
Ricardo Vardasca $(\mathbb{D})$ and Domingos Martinho $(\mathbb{D}$
}

\begin{abstract}
Diabetes mellitus (DM) is a fast-growing metabolic condition that threatens human population quality of living in the overcoming decades. One of its severe consequences is diabetic foot ulcers (DFU), which affect up to a quarter of the DM patients in their lifetime. This consequence leads to high health costs and significant decrease of the patients' quality of life and self-esteem. In order to cope with the rising demands of heath resources and shortage in clinical human assets intelligent computational tools are required to aid in the decision where a patient is in an early stage of a DFU development and on the appraisal of a DFU treatment. It is aim of this research to provide a critical overview of the existing decision support systems (DSS) and publicly available research datasets for diabetic foot ulcers early diagnosis and treatment assessment, and thus proposing a new infrastructure system to deal with it overcoming the past attempts. The existing DFU DSS failed in being introduced in clinical practice due to total discrepancy with current daily clinical practice with DFU and the publicly available DM research datasets are shorter in data for feeding a new DSS. This research presents the actual and promising future data required for effective decisions and discloses a proposed architecture for a DSS applicable to DFU early diagnosis and treatment evaluation. Implementing the proposed system will take time but it will definitely contribute to cope with the patient demands, associated cost reduction and promotion of patients care.
\end{abstract}

Keywords Big data $\cdot$ Clinical datasets $\cdot$ Decision support systems $\cdot$ Diabetic foot ulcers $\cdot$ Diagnostic tools $\cdot$ Multiple data sources $\cdot$ Treatment assessment

\footnotetext{
R. Vardasca $(\varangle) \cdot$ D. Martinho

ISLA Santarem, Largo Candido Dos Reis, 2000-241 Santarem, Portugal

e-mail: ricardo.vardasca@islasantarem.pt
} 


\section{Introduction}

\subsection{The Problem of Diabetic Foot Ulcers (DFU)}

Diabetes mellitus (DM) is the most affecting metabolic disease, which majorly threatens the population quality of life, being this aggravated with aging and life expectancy evolution. It can present itself in three forms: type 1 (autoimmune reaction caused, no or low insulin is produced), type 2 (caused by aging and lifestyle habits, characterized by insulin resistance), and gestational (temporary, high blood glucose levels during pregnancy). The estimated worldwide incidence of DM according to the International Diabetes Federation (IDF) is 9.3\% for adults aged 20-79 years old, which means one in eleven adults is affected, being the projected rates of $11 \%$ and $13.5 \%$ for the years of 2030 and 2050, respectively, meaning a 51\% increase of the condition [1].

One of the known consequences of DM evolution is the Diabetic Foot Ulcers (DFU), which may affect up to $25 \%$ of the DM patients' population, being the risk of recurrence rate of $40 \%$ within the first year and up to $65 \%$ after five years of healing [2]. This resulting condition can lead in the most severe cases to amputations and consequent death and contributes to the major spending among DM patients' care [3]. With the demand of care caused by the rising of DFU and with limited resources in terms of clinical personal, new intelligent technological instruments are required to facilitate the early identification of DFU and to help on the assessment of its treatments to aid on act promptly to provide the best care possible.

The International Working Group on the Diabetic Foot (IWGDF) in 2019 has defined the guidelines for the classification of diabetic foot ulcers [4], which is an important source of the required data to early detect and characterize a healing DFU.

Since the introduction of Decision Support Systems in medicine in the mid 1950's with the MYCIN that technology proved to be a precious aid to the clinicians daily practice helping them cope with growing demands in clinical care decision, eliminating human error, reducing costs and contributing to provide better overall care to patients [5]. The first known DSS devoted to DFU diagnosis appeared in 2009 for predicting amputations [6].

\subsection{Current DFU Diagnostic and Treatment Assessment Methods}

The current practical guidelines of the IWGDF established in 2019 [4] determined that to deal with DFU the following procedures have to be implemented:

- Prevention of DFU in subjects with DM

- Offloading DFU in subjects with DM 
- Diagnosis, prognosis and management of peripheral artery disease (PAD) in patients with a DFU and DM

- Diagnosis and treatment of DFU infection in subjects with DM

- Interventions to enhance healing of DFU in subjects with DM

- Classification of DFU.

The characterization of DFU patients has a wide spectrum, it involves different geographies, social classes, ages, not specific of a single gender, although it is consensual that it results from a subject with DM and simultaneously having two or more risk factors. The diabetic peripheral neuropathy and PAD usually playing a central role. The first leads to an insensitive and sometimes deformed foot, often causing abnormal loading of the foot. The PAD is characterized by poor circulation in the extremity.

In order to prevent DFU it is very important to Identify the foot at-risk, to regularly inspect and examine the foot at-risk, to educate the patient, his family, and the other healthcare professionals, to ensure routine wearing of appropriate footwear and at least but not less important to treat the risk factors for ulceration.

The current diagnosis is based in the patient history, medical examination of the foot appearance, the vascular status of the limb (which can have its levels of oxygen$\mathrm{O}_{2}$-monitored) and assessment of the Loss of protective sensation (LOPS). The LOPS can be monitored through the patient pressure perception using the SemmesWeinstein $10 \mathrm{~g}$ monofilament test and/or the vibration perception: $128 \mathrm{~Hz}$ tuning fork test.

Based in this assessment the risk of the DFU can be established as presented in Table 1.

Through the history and clinical examination, and DFU can be classified as: neuropathic, neuro-ischemic or ischemic. The measurement of the ankle-brachial index (ABI) using a Doppler instrument is very important for identifying the presence of PAD or not, if it is not present then the DFU is only neuropathic.

For correctly classify the DFU it is important to know the type, cause, site and depth, signs of infection, and patient-related factors.

The severity of infection can be obtained from the IWGDF/ISDA classification criteria (Table 2) if the patient has no PAD but if he has the Wifi system (Table 3)

Table 1 The DFU Risk with the corresponding foot screening frequency by an expert [4]

\begin{tabular}{l|l|l}
\hline Risk & Characteristics of the examination & Frequency of screening \\
\hline Very low & No PAD and no LOPS & Once a year \\
\hline Low & PAD and/or LOPS but no other signs in the foot & Once every 6/12 months \\
\hline Medium & $\begin{array}{l}\text { LOPS+PAD, or LOPS+foot deformity or PAD+foot } \\
\text { deformity }\end{array}$ & Once every $3 / 6$ months \\
\hline $\begin{array}{l}\text { LOPS or PAD, and one or more of the following: } \\
- \text { history of a foot ulcer } \\
- \text { a lower-extremity amputation (minor or major) } \\
- \text { end-stage renal disease }\end{array}$ & Once every $1 / 2$ months \\
\hline
\end{tabular}


Table 2 IWGDF/ISDA classification criteria [4]

\begin{tabular}{l|l}
\hline Clinical manifestations & Infection severity \\
\hline Wound lacking purulence or any manifestations of inflammation & Uninfected \\
\hline $\begin{array}{l}\text { Presence of } \geq 2 \text { manifestations of inflammation (purulence, or erythema, } \\
\text { tenderness, warmth, or induration), but any cellulitis/erythema extends } \\
\leq 2 \mathrm{~cm} \text { around the ulcer, and infection is limited to the skin or superficial }\end{array}$ & Mild \\
subcutaneous tissues; no other local complications or systemic illness & \\
\hline $\begin{array}{l}\text { Infection (as above) in a patient who is systemically well and metabolically } \\
\text { stable, but which has } \geq 1 \text { of the following characteristics: cellulitis } \\
\text { extending }>2 \mathrm{~cm}, \text { lymphangitic streaking, spread beneath the superficial } \\
\text { fascia, deep-tissue abscess, gangrene, and involvement of muscle, tendon, } \\
\text { joint or bone }\end{array}$ & Moderate \\
\hline $\begin{array}{l}\text { Infection in a patient with systemic toxicity or metabolic instability (e.g., } \\
\text { fever, chills, tachycardia, hypotension, confusion, vomiting, leukocytosis, } \\
\text { acidosis, severe hyperglycemia, or azotemia) }\end{array}$ & Severe \\
\hline
\end{tabular}

Table 3 Wifi system

\begin{tabular}{l|l|l}
\hline Wound grade & DFU & Gangrene \\
\hline 0 & No Ulcer & No Gangrene \\
\hline 1 & $\begin{array}{l}\text { Clinical description: minor tissue loss. Salvageable with simple digital } \\
\text { amputation (1 or 2 digits) or skin coverage }\end{array}$ \\
\hline \multirow{2}{*}{$\begin{array}{l}\text { Small, shallow ulcer(s) on distal leg or } \\
\text { foot; no exposed bone, unless limited } \\
\text { to distal phalanx }\end{array}$} & No gangrene \\
\hline & $\begin{array}{l}\text { Clinical description: minor tissue loss. Salvageable with simple digital } \\
\text { amputation (1 or 2 digits) or skin coverage }\end{array}$ \\
\hline 3 & $\begin{array}{l}\text { Deeper ulcer with exposed bone, joint } \\
\text { or tendon; generally, not involving the } \\
\text { heel; shallow heel ulcer, without } \\
\text { calcaneal involvement }\end{array}$ & Gangrenous changes limited to digits \\
\hline & $\begin{array}{l}\text { Clinical description: major tissue loss salvageable with multiple ( } \geq 3) \text { digital } \\
\text { amputations or standard trans metatarsal amputation (TMA) } \pm \text { skin coverage }\end{array}$ \\
\hline & $\begin{array}{l}\text { Extensive, deep ulcer involving } \\
\text { forefoot } \\
\text { and/or midfoot; deep, full thickness } \\
\text { heel ulcer } \pm \text { calcaneal involvement }\end{array}$ & $\begin{array}{l}\text { Extensive gangrene involving forefoot } \\
\text { and/or midfoot; full thickness heal } \\
\text { necrosis with calcaneal involvment }\end{array}$ \\
\hline & $\begin{array}{l}\text { Clinical description: extensive tissue loss salvageable only with a complex foot } \\
\text { reconstruction or non-traditional TMA (Chopart or Lisfranc); flap coverage or } \\
\text { complex wound management needed for large soft tissue defect }\end{array}$ \\
\hline
\end{tabular}

should be used for stratifying the possible amputation risk and revascularization benefit [4].

The DFU can be treated according with the status of the wound, it can be healed through pressure offloading and ulcer protection, restoration of tissue perfusion (surgery), infection treatment (clearance and debride of all necrotic tissue and 
surrounding, oral antibiotic therapy, surgery), metabolic control and treatment of comorbidities (insulin and/or nutrition), local ulcer care (clearance, debride and/or dressings), and education of patient and relatives.

The DFU can be objectively assessed by using the Wagner scale [7, 8] or the University of Texas Diabetic Wound Classification scale [9]. When comparing the two, the second is more descriptive and complete, showing greater association with higher risk of amputation and likelihood of the healing process of ulcers, due to the combination of grade and stage characterization, whether the Wagner scale is simpler and easier to memorize as a visual method, although it does not consider the size, PAD, and LOPS.

\subsection{Promising Technological Instruments for DFU Diagnostic and Treatment Assessment Methods}

Over the recent years, there were some technological advancements that proved their applicability, although those instruments are not yet fully available in daily clinical setting. Foot pressure loading monitoring is possible through the usage of a sensorial system and it aids to identify the point in which the patient may out more pressure and are more likely to generate a DFU [4] given the load and time of exposure, it can be recorded in rest of exercising. Like pressure load, monitoring the gait can also give important indications on the loss of equilibrium and neurological balance in DM patients [10], it can be performed using sensors such as 3 axis accelerometers and gyroscopes. These two information sources could enter as inputs for a DFU diagnostic SSD.

A recent research also proposed a set of biomarkers that can be of great importance for early detection of DFU [11].

Other important information is foot skin temperature, which is influence by both peripheral vascular and autonomic nervous system, it is known that an asymmetrical or variation to the close surroundings over $2.2^{\circ} \mathrm{C}$ is an indicator of possibility of a DFU development one or two weeks before being visible [12]. This type of assessment can be performed using low-cost sensors that require contact $[13,14]$ or remote monitoring through infrared radiation, which are more expensive. There is also the possibility of using infrared thermal (IRT) imaging, which can measure the temperature of large areas of skin and provides a permanent record that can be used for further analysis, this technique has proved to be of importance either in aiding diagnosis through identifying risky areas (of neuropathic and vascular origin) [15] or through assess the outcome of a treatment [16].

In order to objectively assess DFU healing imaging techniques in visual spectrum can offer real estimation of area, volume, shape, and color of the wound $[17,18]$ providing a better characterization, along with the Pressure Ulcer Scale for Healing (PUSH) [19-21], already used for chronic wounds in clinical setting and accommodates the ulcer volume, the type of existing tissue and the amount of exudate, it can 
aid and guide clinicians in a better treatment assessment and in case of poor outcome help to choose a different healing procedure.

Given this and with the recent developments in terms of data analysis and DSSs, it is of major importance to understand where the gaps and opportunities are for its implementation, which is the motivation for this research. The novelty and contribution of this piece of research is to identify the weaknesses of the existing DFU DSS and to disclose the required steps for the implementation of an effective DFU DSS system to give an adequate answer to the growing demand of DM patients care.

It is aim of this research to provide a critical overview of the existing decision support systems and publicly available research datasets for diabetic foot ulcers early diagnosis and treatment assessment, and thus proposing a new infrastructure system to deal with it overcoming the past attempts.

This manuscript is organized in five sections. The first, the current one, introduces the problem, the existing DFU clinical diagnostic and treatments assessment processes and the promising complementary emerging methods. It is followed by a characterization of the existing supportive technology in terms of freely available datasets and DSS implemented and mitigated. In section three a proposal of a new effective DFU DSS is made, it is followed by a discussion between what is proposed and the existing implementations, which is remarked with the conclusions.

\section{Existing Supportive Technology}

In this section, the existing available DM datasets are characterized and the mitigated DFU decision support systems are object of critical assessment.

\subsection{Existing DM Datasets Available for Research}

In Table 4 are described the DM open available datasets that can be used for research, the purpose of its storage, the number of records, and the attributes of each are presented.

It can be easily observed that mostly insulin and blood glucose levels are the only common attributes to all the datasets, this could be explained by the different nature of the original purpose of the dataset, but it is also possible to note that even the more detailed have insufficient data to classify or predict a DFU. 
Table 4 Characterization of the open available DM datasets

\begin{tabular}{|c|c|c|c|}
\hline Size & Purpose & Attributes & References \\
\hline 442 & $\begin{array}{l}\text { Group different DM } \\
\text { patients per attribute }\end{array}$ & $\begin{array}{l}\text { Age (years), Sex, body mass index, bp } \\
\text { (average blood pressure), s1 tc (T-Cells-a } \\
\text { type of white blood cells), s2 ldl (low-density } \\
\text { lipoproteins), s3 hdl (high-density } \\
\text { lipoproteins), s4 tch (thyroid stimulating } \\
\text { hormone), s5 ltg (lamotrigine), s6 glu (blood } \\
\text { sugar level) }\end{array}$ & [22] \\
\hline 6742 & $\begin{array}{l}\text { Progression of diabetic } \\
\text { kidney disease and } \\
\text { trajectory of kidney } \\
\text { function decline }\end{array}$ & $\begin{array}{l}\text { BMI, End-stage renal disease in type } 2 \\
\text { diabetics, Fasting insulin, Chronic kidney } \\
\text { disease in type } 2 \text { diabetics, Coronary artery } \\
\text { disease in type } 2 \text { diabetics, Coronary heart } \\
\text { disease or stroke or peripheral vascular } \\
\text { disease in type } 2 \text { diabetics, eGFR-creat (serum } \\
\text { creatinine), HDL cholesterol, Height, } \\
\text { HOMA-B, Insulinogenic index, LDL } \\
\text { cholesterol, Microalbuminuria, } \\
\text { Macroalbuminuria vs. controls, Total } \\
\text { cholesterol, Triglycerides, Type } 2 \text { diabetes, } \\
\text { Urinary albumin-to-creatinine ratio, Waist } \\
\text { circumference }\end{array}$ & $\begin{array}{l}\text { Jiang et al. } \\
{[23]}\end{array}$ \\
\hline 768 & $\begin{array}{l}\text { Verify whether patient } \\
\text { shows signs of diabetes } \\
\text { according to WHO } \\
\text { criteria }\end{array}$ & $\begin{array}{l}\text { Number of times pregnant, Plasma glucose } \\
\text { concentration } 2 \mathrm{~h} \text { in an oral glucose tolerance } \\
\text { test, Diastolic blood pressure, Triceps skin } \\
\text { fold thickness, } 2 \mathrm{~h} \text { serum insulin, Body mass } \\
\text { index, Diabetes pedigree function, Age } \\
\text { (years), Class variable }\end{array}$ & [24] \\
\hline 11,830 & $\begin{array}{l}\text { General patient data for } \\
\text { characterization }\end{array}$ & $\begin{array}{l}\text { ID,Description, Affected Status, Product, } \\
\text { Source, Gene, Mutations, Sex, Age at } \\
\text { Sampling, Race, Ethnicity }\end{array}$ & [25] \\
\hline 70 & $\begin{array}{l}\text { General DM data of } \\
\text { country/region/world } \\
\text { overtime }\end{array}$ & $\begin{array}{l}\text { Country/Region/World, ISO, Sex, Year, Crude } \\
\text { diabetes prevalence, Lower } 95 \% \text { uncertainty } \\
\text { interval, Upper 95\% uncertainty interval }\end{array}$ & [26] \\
\hline 45,000 & $\begin{array}{l}70 \text { sets of data recorded } \\
\text { on diabetes patients }\end{array}$ & $\begin{array}{l}\text { Date, Time, Code, Value, Regular insulin } \\
\text { dose, NPH insulin dose, UltraLente insulin } \\
\text { dose, Unspecified blood glucose } \\
\text { measurement, Unspecified blood glucose } \\
\text { measurement, Pre-breakfast blood glucose } \\
\text { measurement, Post-breakfast blood glucose } \\
\text { measurement, Pre-lunch blood glucose } \\
\text { measurement, Post-lunch blood glucose } \\
\text { measurement, Pre-supper blood glucose } \\
\text { measurement, Post-supper blood glucose } \\
\text { measurement, Pre-snack blood glucose } \\
\text { measurement, Hypoglycemic symptoms, } \\
\text { Typical meal ingestion, More-than-usual meal } \\
\text { ingestion, Less-than-usual meal ingestion, } \\
\text { Typical exercise activity, More-than-usual } \\
\text { exercise activity, Less-than-usual exercise } \\
\text { activity, Unspecified special event }\end{array}$ & [27] \\
\hline
\end{tabular}


Table 4 (continued)

\begin{tabular}{|c|c|c|c|}
\hline Size & Purpose & Attributes & References \\
\hline 1688 & $\begin{array}{l}\text { Demographic } \\
\text { information, diabetes } \\
\text { status, health } \\
\text { indicators, health } \\
\text { behaviors, and Problem }\end{array}$ & $\begin{array}{l}\text { class, class_language, age, year, gender, } \\
\text { insurance_category, medical_home_category, } \\
\text { race_ethnicity, education_level, } \\
\text { diabetes_status_yes_no, } \\
\text { heart_disease_yes_no, } \\
\text { high_blood_pressure_yes_no, } \\
\text { tobacco_use_yes_no, } \\
\text { previous_diabetes_education_yes_no, } \\
\text { diabetes_knowledge, } \\
\text { fruits_vegetable_consumption, } \\
\text { sugar_sweetened_beverage_consumption, } \\
\text { food_measurement, carbohydrate_counting, } \\
\text { exercise, } \\
\text { problem_area_in_diabetes_paid_scale_score, } \\
\text { zip_code_address, zip_code_city, } \\
\text { zip_code_state, zip_code_zip }\end{array}$ & [28] \\
\hline 225 & $\begin{array}{l}\text { Verify whether the use } \\
\text { of continuous glucose } \\
\text { monitoring (CGM) } \\
\text { without blood glucose } \\
\text { monitoring (BGM) } \\
\text { measurements is as } \\
\text { safe and effective }\end{array}$ & $\begin{array}{l}\text { Blood Glucose, Glycated hemoglobin level, } \\
\text { Insulin, Medications, Patient Demographics }\end{array}$ & Aleppo [29] \\
\hline 451 & $\begin{array}{l}\text { Test CGM as a } \\
\text { technology to assist in } \\
\text { diabetes care }\end{array}$ & $\begin{array}{l}\text { Glycated hemoglobin level, Insulin, Patient } \\
\text { Demographics }\end{array}$ & $\begin{array}{l}\text { Tamborlane } \\
{[30]}\end{array}$ \\
\hline 200 & $\begin{array}{l}\text { Identify factors } \\
\text { associated with severe } \\
\text { hypoglycemia in older } \\
\text { adults }(60+) \text { with type } \\
1 \text { diabetes }\end{array}$ & Insulin, Medications, Patient Demographics & $\begin{array}{l}\text { Weinstock } \\
{[31]}\end{array}$ \\
\hline
\end{tabular}

\subsection{Existing DSS for DFU Diagnostic and Treatment Assessment Methods}

In Table 5 are present the existing decision support systems for DFU, divided by type of DSS, informing the purpose, the used data, and the achieved assessment results. It is important to note that ANN refers to Artificial Neural Networks, acc to accuracy, CNN to Conversional Neural Networks, LDA to Local Discriminant Analysis, SVM to Support Vector Machines, k-NN to k-Nearest Neighbor, GA to Genetic Algorithms, and AUC to Area Under the Curve.

From Table 5, it can be seen that the majority of the DFU DSS are concerned with the classification of the data, only one was applied to risk identification [32] and another to the prediction of amputation [33]. Apart from [44] most of the samples used are very small $(<2500)$. Only four DSS assess the treatment outcome $[35,36$, 
Table 5 Characterization of the existing DFU for diagnostic and treatment assessment

\begin{tabular}{|c|c|c|c|c|}
\hline Type & Purpose & Used data & Assessment result & References \\
\hline Risk analysis & $\begin{array}{l}\text { Predicting the risk } \\
\text { of DFU }\end{array}$ & $\begin{array}{l}255 \text { samples of } \\
\text { genotype data }\end{array}$ & ANN: $83 \%$ acc & Singh et al. [32] \\
\hline Prediction & $\begin{array}{l}\text { Predicting the } \\
\text { amputation in DM } \\
\text { patients with } \\
\text { record of DFU }\end{array}$ & $\begin{array}{l}237 \text { samples of } \\
\text { amputation data }\end{array}$ & $\begin{array}{l}\text { Logistic } \\
\text { regression and } \\
\text { Bayesian network } \\
\text { AUC } 0.765\end{array}$ & Hüsers et al. [33] \\
\hline Classification & $\begin{array}{l}\text { Identify the extent } \\
\text { of risk factors for } \\
\text { major and minor } \\
\text { amputations in } \\
\text { patients with DFU }\end{array}$ & $\begin{array}{l}2321 \text { samples of } \\
\text { historical records } \\
\text { of DM patient's } \\
\text { medical history }\end{array}$ & $\begin{array}{l}\text { Decision tree, } \\
\text { validated the } \\
\text { international } \\
\text { guidelines }\end{array}$ & $\begin{array}{l}\text { Widatalla et al. } \\
{[6]}\end{array}$ \\
\hline Classification & $\begin{array}{l}\text { Feature extraction } \\
\text { and consequent } \\
\text { classification into } \\
\text { ischemic and } \\
\text { non-ischemic or } \\
\text { infection and } \\
\text { non-infection } \\
\end{array}$ & 1459 DFU images & $\begin{array}{l}\text { Ensemble CNN, } \\
90.3 \% \text { acc } \\
\text { ischemic } 72.7 \% \\
\text { acc infection }\end{array}$ & $\begin{array}{l}\text { McInnes et al. } \\
\text { [34] }\end{array}$ \\
\hline Classification & $\begin{array}{l}\text { Classification of } \\
\text { wound status }\end{array}$ & $\begin{array}{l}1000 \text { samples of } \\
\text { historical records } \\
\text { of DM patient's } \\
\text { medical history }\end{array}$ & $\begin{array}{l}\text { logistic regression } \\
\text { classifier, error of } \\
\text { prediction of } \\
2.8 \%\end{array}$ & Yuan et al. [35] \\
\hline Classification & $\begin{array}{l}\text { Classification of } \\
\text { microbial species } \\
\text { from DFU }\end{array}$ & 1750 samples & $\begin{array}{l}\text { LDA+SVM } \\
99.8 \% \text { acc }\end{array}$ & Yusuf et al. [36] \\
\hline Classification & $\begin{array}{l}\text { Classify correctly } \\
\text { the locations of the } \\
\text { DFU in the thermal } \\
\text { images }\end{array}$ & $\begin{array}{l}39 \text { dynamic } \\
\text { infrared images of } \\
\text { DFU patients }\end{array}$ & SVM $87.5 \%$ acc & $\begin{array}{l}\text { Vardasca et al. } \\
\text { [37] }\end{array}$ \\
\hline Classification & $\begin{array}{l}\text { Automatic } \\
\text { classification of the } \\
\text { DFU according to } \\
\text { their nature }\end{array}$ & $\begin{array}{l}54 \text { infrared images } \\
\text { of DFU patients }\end{array}$ & k-NN $93.4 \%$ acc & $\begin{array}{l}\text { Vardasca et al. } \\
{[38]}\end{array}$ \\
\hline Classification & $\begin{array}{l}\text { Early detection of } \\
\text { DFU considering } \\
\text { asymmetry }\end{array}$ & $\begin{array}{l}100 \text { thermal } \\
\text { images of DM } \\
\text { patients }\end{array}$ & $\begin{array}{l}\text { Otsu's method } \\
\text { and GA, } \\
\text { misclassification } \\
\text { error of } 0.034\end{array}$ & $\begin{array}{l}\text { Kaabouch et al. } \\
\text { [39] }\end{array}$ \\
\hline Classification & $\begin{array}{l}\text { Classify into } \\
\text { healthy and } \\
\text { abnormal skin }\end{array}$ & 754 foot images & SVM $94.5 \%$ acc & $\begin{array}{l}\text { Alzubaidi et al. } \\
\text { [40] }\end{array}$ \\
\hline Classification & $\begin{array}{l}\text { Classify pressure } \\
\text { into healthy } \\
\text { controls, DM } \\
\text { controls and DM } \\
\text { neuropathic }\end{array}$ & $\begin{array}{l}84 \text { samples of } \\
\text { dynamic plantar } \\
\text { pressure }\end{array}$ & SVM $96.4 \%$ acc & Botros et al. [41] \\
\hline
\end{tabular}


Table 5 (continued)

\begin{tabular}{|c|c|c|c|c|}
\hline Type & Purpose & Used data & Assessment result & References \\
\hline Classification & $\begin{array}{l}\text { Classify into } \\
\text { normal and } \\
\text { abnormal skin }\end{array}$ & 397 foot images & CNN $94.5 \%$ acc & Goyal et al. [42] \\
\hline Classification & $\begin{array}{l}\text { Localization of the } \\
\text { DFU in the images }\end{array}$ & 1880 foot images & CNN $91.8 \%$ & Goyal et al. [43] \\
\hline Classification & $\begin{array}{l}\text { Classifying into } \\
\text { healing and } \\
\text { non-healing } \\
\text { wounds }\end{array}$ & $\begin{array}{l}\text { 53,354 samples of } \\
\text { demographic and } \\
\text { wound } \\
\text { information }\end{array}$ & $\begin{array}{l}\text { Gradient Boost } \\
\text { Tree models, } \\
\text { AUC } 0.842\end{array}$ & Jung et al. [44] \\
\hline Classification & $\begin{array}{l}\text { Wound } \\
\text { classification into } \\
\text { tissue types }\end{array}$ & 50 wound images & SVM $88 \%$ acc & $\begin{array}{l}\text { Wannous et al. } \\
{[45]}\end{array}$ \\
\hline Classification & $\begin{array}{l}\text { Separate } \\
\text { background from } \\
\text { feet and identify } \\
\text { correctly the DFU }\end{array}$ & $\begin{array}{l}76 \text { thermal images } \\
\text { of DM patient foot }\end{array}$ & $\begin{array}{l}\text { Clustering } \\
\text { k-means, } 99.1 \% \\
\text { acc }\end{array}$ & Liu et al. [46] \\
\hline Classification & $\begin{array}{l}\text { Separate } \\
\text { background from } \\
\text { feet and identify } \\
\text { correctly the DFU }\end{array}$ & $\begin{array}{l}26 \text { visual spectrum } \\
\text { and thermal } \\
\text { images }\end{array}$ & $\begin{array}{l}\text { Clustering } \\
\text { k-means, } 98.25 \%\end{array}$ & Niri et al. [47] \\
\hline Classification & $\begin{array}{l}\text { Classify the risk of } \\
\text { non-healing in } \\
\text { DFUs }\end{array}$ & $\begin{array}{l}\text { Hyperspectral } \\
\text { images }\end{array}$ & PCA 0.66 AUC & Yang et al. [48] \\
\hline
\end{tabular}

$44,45]$, most are concerned with the diagnosis [6, 32-34, 37-42, 48] and other three with the correct location of the DFU in images [43, 46, 47]. The classification method that presents most application is the SVM, good accuracy (acc $>92 \%$ ) is reported by most of the studies [36, 38, 40-42, 46, 47].

\section{Proposed Intelligent Effective DSS for Diagnostic and Treatment Assessment Methods}

From the previous section, it can be seen that the available datasets are insufficient for effectively aiding with DFU early diagnosis and treatment assessment, there are relevant data missing. Also, the existing DSS do not take into account the current IWGDF guidelines, which is the current clinical daily practice. Most of the used data by the previously implemented DSS was generated and read for the application, being small and dedicated.

In order to address the problematic, it is important to reformulate the data sources and make sure that is possible to achieve all the required data. The DM patient historic data is present on his electronic patient record (EPR), every time a patient undergoes a 
expert examination because of a suspicious DFU, all the collected data on that consult should be stored in a regular consult DB, which can be linked with the EPR or not. Most patients nowadays use gadgets to monitor their health parameters, in special DM patients must verify their blood glucose level twice a day and they can record it along other parameters in an app in their smartphones with the possibility of having a cloud database to store that data. When they have a DFU that requires treatment, the general practitioner should document the intervention on a database. If any of the promising methods that were described in Sect. 1.3 are available, they can also be documented and stored in a database, it is important that the biomarkers due to its nature to be stored in a different data source. All this data stored in different sources is a challenge to a DSS implementation, it requires remote access to it and a lot of ETL and data preparation, in order to this be transformed and loaded into different data marts that will constitute the DFU data warehouse. Then intelligence will be added through Online Analytic Processing (OLAP) and Data Mining methods (which can be object of further research) to finally make knowledge visible in a dashboard through intelligent and simplified charts. This is the basis for the architecture proposed and present in Fig. 1.

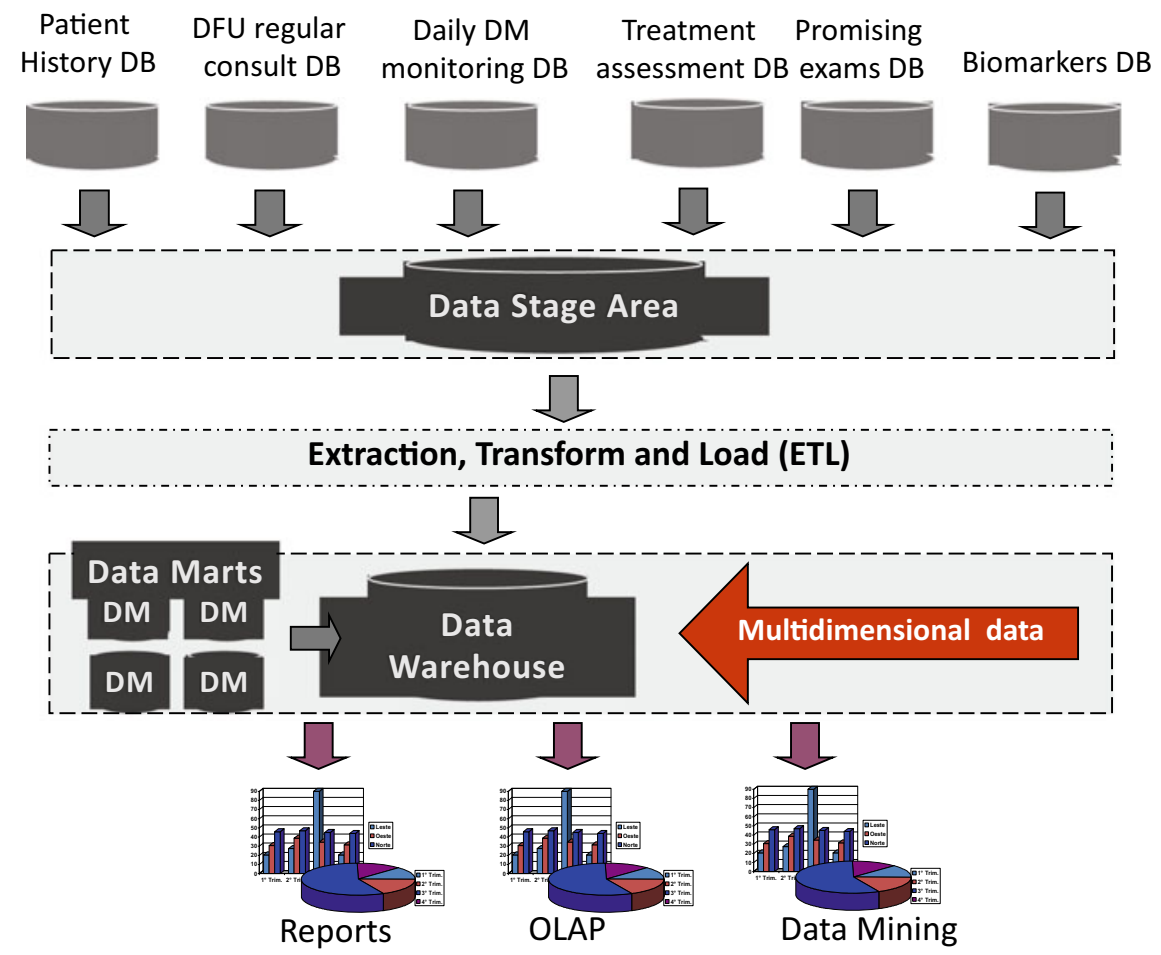

Fig. 1 The architecture of the proposed effective DSS for DFU diagnosis and treatment assessment 
It is important to bear in mind that in the beginning there are two situations: we can be looking for the unknown and then unsupervised methods such as clustering, or aggregation rules should be used to implement the data mining models. On the other hand, if we have a hint and previous knowledge about the classification that we intend, depending on the data (continuous or discrete) and on how many classes are expected, SVM, ANN, k-NN, GA among other methods should be used. When trying to establish a prediction linear or logistic regression should be considered. It is not the intention of this research to propose combinations of data mining methods or suggesting models, or even suggesting implementation technologies, it would only make sense when the data sources were adequately available.

\section{Discussion}

The increase of DM and consequent DFU is a growing problem and burden to every health system, soon the demand will be so high that the health resource will find difficulties to cope with the care requirements, intelligent systems are needed to ease that scenario and to help reducing the associated costs. Preventing will always be cheaper than healing.

From this research, it can be observed that with the existing freely available datasets on DM it cannot be implemented an effective DSS for DFU diagnosis and treatment assessment. Also, the majority of the implemented and tested DFU DSS only addressed a specific question, being very simple to be of future value for the demanding. Most are resultant of academic research and will be difficult to be implemented in clinical daily practice, so the proposed open architecture is dynamic in allowing multiple questions, which through OLAP and data mining is possible to adjust to the required question. It was not found in the literature any implementation of this kind for dealing with DFU. This is first step toward a technological need. To date from the presented existing DSS it seems that developers are not aware of DFU daily practice in clinical setting and it is important to have in mind that is easier to adapt the computational tools to the health professional than the opposite, due to their afraid of losing a job to a smart system the show resistance in this systems adoption, so they have to feel that these tools are useful and only will act as facilitator in their practice.

\section{Conclusion}

The existing DFU DSS are insufficient for the early identification of feet at risk and to assess objectively the DFU treatments. The public available datasets are not in agreement with the current clinical information process required to make decisions nor with the emerging technologies and their objective data. A redefinition of new data sources in line with the IWGDF protocol is required, this along with new emerging related data sources would constitute DM to form a larger DW are essential for more 
effective Data mining, data analysis, OLAP and Visual dashboards to aid effective DFU decision making.

Only with the implementation of a system as suggested it will definitely contribute to cope with the patient demands, associated cost reduction and promotion of patients care.

\section{References}

1. International Diabetes Federation: IDF diabetes atlas, 9th edn. International Diabetes Federation, Brussels

2. Chatwin KE, Abbott CA, Boulton AJ, Bowling FL, Reeves ND (2020) The role of foot pressure measurement in the prediction and prevention of diabetic foot ulceration-a comprehensive review. Diabet Metabol Res Rev 36(4):e3258

3. Schreml S, Berneburg M (2017) The global burden of diabetic wounds. Br J Dermatol 176(4):845-846

4. Monteiro-Soares M, Russell D, Boyko EJ, Jeffcoate W, Mills JL, Morbach S et al (2020) International working group on the diabetic foot (IWGDF) Guidelines on the classification of diabetic foot ulcers (IWGDF 2019). Diabet Metabol Res Rev 36:e3273

5. Zhou L, Sordo M (2021) Expert systems in medicine. In: Artificial intelligence in medicine, pp 75-100. Academic Press

6. Widatalla AH, Mahadi SEI, Shawer MA, Elsayem HA, Ahmed ME (2009) Implementation of diabetic foot ulcer classification system for research purposes to predict lower extremity amputation. Int J Diabet Dev Countr 29(1):1

7. Wagner FW Jr (1981) The dysvascular foot: a system for diagnosis and treatment. Foot Ankle 2(2):64-122

8. Wagner FW Jr (1986) The diabetic foot and amputation of the foot. In: Mann RA (ed) Surgery of the Foot, 5th edn, pp 421-455. Mosby, St Louis

9. Lavery LA, Armstrong DG, Harkless LB (1996) Classification of diabetic foot wounds. J Foot Ankle Surg 35(6):528-531

10. Scarton A, Guiotto A, Malaquias T, Spolaor F, Sinigaglia G, Cobelli C, Sawacha Z (2018) A methodological framework for detecting ulcers' risk in diabetic foot subjects by combining gait analysis, a new musculoskeletal foot model and a foot finite element model. Gait Posture 60:279-285

11. Wang Y, Shao T, Wang J, Huang X, Deng X, Cao Y, Zhao C et al (2020) An update on potential biomarkers for diagnosing diabetic foot ulcer at early stage. Biomed Pharmacother 133:110991

12. Wijlens AM, Holloway S, Bus SA, van Netten JJ (2017) An explorative study on the validity of various definitions of a $2 \cdot 2 \mathrm{C}$ temperature threshold as warning signal for impending diabetic foot ulceration. Int Wound J 14(6):1346-1351

13. Bus SA (2016) Innovations in plantar pressure and foot temperature measurements in diabetes. Diabetes Metab Res Rev 32:221-226

14. Martín-Vaquero J, Hernández Encinas A, Queiruga-Dios A, José Bullón J, Martínez-Nova A, Torreblanca González J, Bullón-Carbajo C (2019) Review on wearables to monitor foot temperature in diabetic patients. Sensors 19(4):776

15. Gatt A, Falzon O, Cassar K, Ellul C, Camilleri KP, Gauci J, Chockalingam N (2018) Establishing differences in thermographic patterns between the various complications in diabetic foot disease. Int $\mathrm{J}$ Endocrinol

16. Petrova NL, Donaldson NK, Tang W, MacDonald A, Allen J, Lomas C, Kluwe B (2020) Infrared thermography and ulcer prevention in the high-risk diabetic foot: data from a single-blind multicentre controlled clinical trial. Diabet Med 37(1):95-104 
17. Mukherjee R, Tewary S, Routray A (2017) Diagnostic and prognostic utility of non-invasive multimodal imaging in chronic wound monitoring: a systematic review. J Med Syst 41(3):46

18. Frade RA, Vardasca R, Carvalho R, Mendes J (2017) Automatic classification of ulcers through visual spectrum image. In: European congress on computational methods in applied sciences and engineering, pp 297-305. Springer, Cham

19. Cuddigan J (1997) Pressure ulcer classification: What do we have? What do we need? Adv Wound Care 10(5):13-15

20. Stotts NA, Rodeheaver GT, Thomas DR, Frantz RA, Bartolucci AA, Sussman C, MaklebustAn J (2001) Instrument to measure healing in pressure ulcers: development and validation of the pressure ulcer scale for healing (PUSH). J Gerontol A Biol Sci Med Sci 56(12):795-799

21. Thomas DR, Rodeheaver GT, Bartolucci AA, Franz RA, Sussman C, Ferrell BA, Maklebust J (1997) Pressure ulcer scale for healing: derivation and validation of the PUSH tool. Adv Wound Care 10(5):96-101

22. Trevor Hastie's Home Page. https://www4.stat.ncsu.edu/ boos/var.select/diabetes.html. Accessed 29 Nov 2020

23. Jiang G, Luk AOY, Tam CHT, Xie F, Carstensen B, Lau ESH, Ozaki R (2019) Progression of diabetic kidney disease and trajectory of kidney function decline in Chinese patients with type 2 diabetes. Kidney Int 95(1):178-187

24. Pima Indians Diabetes Database. https://datahub.io/machine-learning/diabetes\#readme. Accessed 29 Nov 2020

25. Coriell Institute for Medical Research databank. https://www.coriell.org/Search?q=DIA BETES. Accessed 29 Nov 2020

26. NCD Risk Factor Collaboration (NCD-RisC) evolution of Diabetes overtime. https://ncdrisc. org/data-downloads-diabetes.html. Accessed 29 Nov 2020

27. University of California Machine Learning Repository-Diabetes dataset, https://archive.ics. uci.edu/ml/datasets/diabetes. Accessed 29 Nov 2020

28. Austin Public Health Diabetes Self-Management Education Participant Demographics 20152017. https://data.world/cityofaustin/48iy-4sbg. Accessed 29 Nov 2020

29. Aleppo (2017) Diabetes dataset. https://github.com/irinagain/Awesome-CGM/wiki/Aleppo. Accessed 29 Nov 2020

30. Tamborlane (2008) diabetes dataset. https://github.com/irinagain/Awesome-CGM/wiki/Tam borlane. Accessed 29 Nov 2020

31. Weinstock (2016) diabetes database. https://github.com/irinagain/Awesome-CGM/wiki/Wei nstock. Accessed 29 Nov 2020

32. Singh K, Singh VK, Agrawal NK, Gupta SK, Singh K (2013) Association of Toll-like receptor 4 polymorphisms with diabetic foot ulcers and application of artificial neural network in DFU risk assessment in type 2 diabetes patients. BioMed Res Int

33. Hüsers J, Hafer G, Heggemann J, Wiemeyer S, John SM, Hübner UH (2020) Predicting the amputation risk for patients with diabetic foot ulceration-a bayesian decision support tool. BMC Med Inform Decis Making20

34. McInnes MD, Moher D, Thombs BD, McGrath TA, Bossuyt PM, Clifford T, Hunt HA et al (2018) Preferred reporting items for a systematic review and meta-analysis of diagnostic test accuracy studies: the PRISMA-DTA statement. Jama 319(4):388-396

35. Yuan Z, Huang J, Zhao Z, Zahid A, Heidari H, Ghannam R, Abbasi QH (2018) A compact wearable system for detection and estimation of open wound status in diabetic patient. In: 2018 IEEE Asia Pacific conference on postgraduate research in microelectronics and electronics, pp 60-63

36. Yusuf N, Zakaria A, Omar MI, Shakaff AYM, Masnan MJ, Kamarudin LM, Yasin MS (2015) In-vitro diagnosis of single and poly microbial species targeted for diabetic foot infection using e-nose technology. BMC Bioinform 16(1):158

37. Vardasca R, Magalhaes C, Seixas A, Carvalho R, Mendes J (2019) Diabetic foot monitoring using dynamic thermography and AI classifiers. In: Proceedings of the 3rd quantitative infrared thermography Asia conference (QIRT Asia 2019), Tokyo, Japan, pp 1-5 
38. Vardasca R, Vaz L, Magalhães C, Seixas A, Mendes J (2018) Towards the diabetic foot ulcers classification with infrared thermal images. In: 14th Quantitative infrared thermography conference, Berlin, Germany

39. Kaabouch N, Hu WC, Chen Y, Anderson JW, Ames F, Paulson R (2010) Predicting neuropathic ulceration: analysis of static temperature distributions in thermal images. J Biomed Opt 15(6):061715

40. Alzubaidi L, Fadhel MA, Oleiwi SR, Al-Shamma O, Zhang J (2020) DFU_QUTNet: diabetic foot ulcer classification using novel deep convolutional neural network. Multimedia Tools Appl 79(21):15655-15677

41. Botros FS, Taher MF, ElSayed NM, Fahmy AS (2016) Prediction of diabetic foot ulceration using spatial and temporal dynamic plantar pressure. In: 2016 8th Cairo international biomedical engineering conference (CIBEC), pp 43-47

42. Goyal M, Reeves ND, Davison AK, Rajbhandari S, Spragg J, Yap MH (2018) Dfunet: Convolutional neural networks for diabetic foot ulcer classification. IEEE Trans Emerg Topics Comput Intell

43. Goyal M, Reeves ND, Rajbhandari S, Yap MH (2018) Robust methods for real-time diabetic foot ulcer detection and localization on mobile devices. IEEE J Biomed Health Inform 23(4):1730-1741

44. Jung K, Covington S, Sen CK, Januszyk M, Kirsner RS, Gurtner GC, Shah NH (2016) Rapid identification of slow healing wounds. Wound Repair Regener 24(1):181-188

45. Wannous H, Lucas Y, Treuillet S (2010) Enhanced assessment of the wound-healing process by accurate multiview tissue classification. IEEE Trans Med Imaging 30(2):315-326

46. Liu C, van Netten JJ, Van Baal JG, Bus SA, van Der Heijden F (2015) Automatic detection of diabetic foot complications with infrared thermography by asymmetric analysis. J Biomed Opt 20(2):026003

47. Niri R, Lucas Y, Treuillet S, Douzi H (2019) Smartphone-based thermal imaging system for diabetic foot ulcer assessment. Sorbonne Universités, Paris, France, Journées d'Etude sur la TéléSanté

48. Yang Q, Sun S, Jeffcoate WJ, Clark DJ, Musgove A, Game FL, Morgan SP (2018) Investigation of the performance of hyperspectral imaging by principal component analysis in the prediction of healing of diabetic foot ulcers. J Imaging 4(12):144 